\title{
PUBLIKUMSUDVIKLING STRATEGIER FOR INDDRAGELSE ELLER INSTITUTIONEL UDVIKLING?
}

\section{AUDIENCE DEVELOPMENT - STRATEGIES FOR INVOLVEMENT OR INSTITU-} TIONAL DEVELOPMENT? I The term 'audience development' is currently employed in cultural policy and within art institutions in order to address questions concerning cultural participation. It centers on two parallel discussions: On the one hand it addresses participation as a democratic ideal, and on the other hand it frames specific forms of audience engagement and the inherent and diverging understandings of participation. This article shows how the discourse developed about audience development reduces the discussion to either legitimizing existing cultural policy practice or to strategies for arts marketing, and it suggests that other important perspectives from e.g. performance studies are overlooked in the discussion of art institutions and their current dilemmas. The article presents a model that sums up four parallel discussions unfolding about audience development: cultural practices, aesthetic strategies for interaction, post performance reflections and everyday life. It is argued that all of these four perspectives need to be addressed for audience development to sincerely challenge the prevailing understanding of art institutions and their current dilemmas.

KEYWORDS I audience development; art institutions; cultural policy; audience involvement; active/passive

\section{Publikumsudvikling: En introduktion med afscet i tre eksempler}

Der er overraskelse i blikkene og smil om munden i den københavnske metro, da Copenhagen Phil, det tidligere Sjællands Symfoniorkester, lancerer sit sæsonprogram med en flashmob (I7. april 20I2). Den ene rejsende efter den anden afslører et skjult instrument, og hurtigt er en kammerudgave af orkestret i fuld gang med et uddrag fra Peer Gynt-suiten. Happeningen optages, redigeres og lægges på YouTube og har siden haft mere end 8 mio. hits.

Med en formuleret intention om at "fejre Canadas individualitet og diversitet" opfordrede Art Gallery of Ontario, Canada, publikum og lokalbefolkningen til at indsende deres egne portrætter til en stor portrætudstilling. Eneste begrænsning var et krav om, at formatet skulle være $4 \times 4$ tommer. Initiativet var et led i relan- 
ceringen af galleriet, og det resulterede i udstillingen In Your Face (2006-2007), der samlede mere end 17.000 portrætter.

"Giv publikum ordet og skab samtale om kunst". Det er intentionen med Kunst-o-meter, som er en specialdesignet fotoboks, hvor publikum fortæller om deres oplevelser af den amerikanske videokunstner Bill Violas videoinstallationen Tristan's Ascension. Installationen er permanent på Stavanger Kunstmuseum, og på museets hjemmeside er en række af disse korte fortællinger klippet sammen til en video, som indgår i museets formidling. ${ }^{.}$Kunst-o-meter blev præmieret for bedste formidlingstiltag af det norske museumsforbund i 2012.

En flashmob med Copenhagen Phil i den københavnske metro, en udstilling med I7.00o portrætter i, for og af et canadisk lokalsamfund og en række personlige indtryk af en videoinstallation fortalt til en videoboks på et norsk museum. Hvad kan vi bruge disse tre eksempler til?

Fælles for de tre er, at de alle er eksempler på kulturinstitutioners ønske om at forny deres relationer til deres publikum og til det omgivende (lokal)samfund. Alle tre er også eksempler på tiltag, der med reference til hhv. de høje tal for download og deltagelse og til museumsforbundets præmiering kan betegnes som succesfulde. Og alle tre indeholder et element af overskridelse - en overskridelse af rammerne for institutionernes daglige praksis og en overskridelse af publikums rolle heri. Det er eksempler på vellykkede tiltag, der imødekommer nøgleord som engagement og involvering. Kort sagt: Alle tre er gode eksempler på, hvad man med aktuelt kulturpolitisk sprogbrug kan betegne som publikumsudvikling.

Samtidig adskiller de tre eksempler sig også på afgørende punkter. Mens alle tre sætter relationen mellem institution, værk og publikum til forhandling, er der stor forskel på, hvordan og $\mathrm{i}$ hvilket omfang denne forhandling foregår. I det første, Copenhagen Phils flashmob, rykker institutionen selv ud af sine vante omgivelser, i det andet, portrætudstillingen på Art Gallery of Ontario, inviteres publikum til at være med til at udfylde galleriets vægge, mens det i den tredje, Stavanger Kunstmuseums permanente installation In Your Face, er den fagprofessionelles formidling af et givent kunstværks ide og kvalitet, som nedtones til fordel for det almene publikums ganske forskellige fortolkninger og associationer.

Engagement og involvering betyder med andre ord noget forskelligt $i$ hvert af disse eksempler, og de giver mulighed for at diskutere forestillinger om deltagelse, som de kommer til udtryk i forskellige institutionernes arbejde med at forny relationen mellem institution, værk og publikum. Også i den forstand er eksemplerne illustrative for diskursen om publikumsudvikling. Betegnelsen dækker nemlig over en række forskellige interesser og mål, og der er et behov for at kunne skelne mere klart mellem de delvist modsatrettede idealer, som publikumsudvikling kan dække over (Kawashima, Hansen, Lindelof \& Sjöberg, Winkelhorn). Sådanne modsatrettede idealer er indbygget i betegnelsen selv - for er det virkelig publikum, der skal udvikles? Med andre ord kan man spørge: Hvorfor ikke slet og ret afvise

Videon kan ses på https://www.youtube.com/user/Stavangerkunstmuseum/videos (besøgt 15.06 2014) betegnelsen og tale om kulturinstitutionernes dilemmaer med andre ord? Det er der flere grunde til.

For det første er publikumsudvikling tilsyneladende en accepteret ramme for at tale om kunstinstitutionernes udfordringer, også selvom betegnelsen ofte problematiseres (Hansen, Winkelhorn, Lindelof Audience Development and its blind spot). Også i kulturlivet mærkes en vis skepsis over for selve ordet, men alligevel optræder det i stigende grad i kulturpolitiske dokumenter såvel som i stillingsbetegnelser hos institutionerne og i kulturpolitisk forskning. Når ressourcer øremærkes til publikumsudviklende initiativer, finder formuleringer om publikum og publikumsudvikling vej ind i institutioners vokabularium. Det er derfor vigtigt at forstå den friktion, som er indbygget i betegnelsen selv.

For det andet er de tre eksempler såkaldt best practice, som den diskuteres og formidles af professionelle interessegrupper, hvis formål er at skabe en "platform for senior cultural professionals to talk about all the things that motivate cultural audiences to attend - and enjoy creative experiences", som det hedder hos den relativt nyetablerede interesseorganisation Audiences Europe Network. ${ }^{2}$ Kunstinstitutionerne er under pres fra fremvæksten af en stærk forbrugerkultur, omfattende medialiseringsprocesser og oplevelsesøkonomisk tankegods. Her udfordres de etablerede kunstinstitutioner af det midlertidige, urbane, digitale, bærbare og interaktive; nøgleord som signalerer en afstand til den institutionaliserede kunstproduktion og -formidling. Publikumsudvikling er med andre ord en reaktion på den aktuelle situationen for teatre, koncertsale og museer i den vestlige verden: oplevelsen af, at publikum falder i antal, mens dets gennemsnitsalder stiger. Selvom der til stadighed er uenighed om, hvordan man kan måle kulturel deltagelse (Tepper $\&$ Gao, Hansen), er der generel enighed om, at uddannelsesniveau og dernæst alder er afgørende for, i hvilket omfang den enkelte benytter de statsligt finansierede kulturelle tilbud (Vestheim). Her signalerer publikumsudvikling et organisatorisk fokus på kunstinstitutionernes samfundsmæssige rolle.

For det tredje er hverken én stigende interesse for publikum eller sammenblandingen af diskurser om deltagelse særegent for publikumsudvikling. Tværtimod efterstræbes engagement, involvering og medskabelse i mange sammenhænge, hvor forestillinger om sociale netværk, græsrodsdemokrati og kunstens frigørende potentiale fejres i en uskøn blanding med neoliberalistisk iscenesættelse af deltagelse, der gøres til middel i en stadig øget forbrugerkultur (Couldry, Skot-Hansen Byen som scene). Det er derfor også nødvendigt at fokusere på den diskursive dimension af publikumsudvikling, som er central for produktionen af mening og forskel i kulturlivet (Hall). Diskursiv realisme (Schrøder et al., $44 \mathrm{ff}$ ) fremhæver sprogets konstituerende rolle: 'Publikum', f.eks., bruges som en bred generisk betegnelse på trods af mangfoldige og foranderlige tilskuerroller og deltagelsesformer (Butsch 3). Tilsvarende påvirker den måde som institutionerne opfatter deres publikum på, noget i forhold til, hvilke forestillinger om forholdet mellem kunsten, publikum

2 http://www.audienceseurope.net/page/about-aen (besøgt 15.05.14) 
og institutionen, der overhovedet er mulige. Eller som publikumsforsker Richard Butch tørt konstaterer: "Most often talking about audiences has occurred when others have considered them problematic" (Butsch, I). Gennem en problematisering af den ukritiske forestilling om deltagelse, der kendetegner dele af publikumsudviklingsdiskursen, er det artiklens formål at diskutere en mere generel ambivalens og dermed at bruge publikumsudvikling som prisme for en bredere diskussion af, hvad deltagelsens æstetik indebærer.

\section{Eksisterende perspektiver på publikumsudvikling}

Så hvad er publikumsudvikling? Det umiddelbare svar på det spørgsmål er, at publikumsudvikling er en samlebetegnelse for en række forskelligartede tiltag i kultursektoren, og det er et eksempel på, hvordan deltagelse er et omdrejningspunkt i samtidens diskurs om kunst og kultur. Diskursen omkring publikumsudvikling har udviklet sig over de seneste to årtier, først især i England og Holland (Maitland, Kawashima) og herfra videre til bl.a. de nordiske lande (Danielsen, Hansen, Aidt et al., Winkelhorn, Lindelof Audience Development..., Forsare and Lindelof). I dag er publikumsudvikling et aktuelt kulturpolitisk satsningsområde på både nordisk og europæisk plan.

En af de første der bidrog til at systematisere viden om publikumsudvikling, er den kulturpolitiske forsker Nobuko Kawashima. Hendes indflydelsesrige undersøgelse sammenfattede de britiske publikumsudviklingsinitiativer i fire forskellige kategorier: I) smagskultivering 2) publikumsuddannelse, 3) udvidet markedsføring og 4) social inklusion/outreach. (Kawashima, 8). Både smagskultivering og publikumsuddannelse henvender sig til det publikum, der allerede kender institutionen. Udvidet markedsføring er en måde at skabe opmærksomhed blandt det potentielle publikum, for hvem institutionens tilbud ikke er fremmed, og alle tre kategorier benytter sig af metoder, som kendes fra arts marketing og æstetiske læreprogrammer. Heroverfor står Kawashimas fjerde kategori, som præsenterer kunsten i uvante omgivelser og for folk, som ikke normalt bruger kunstinstitutionerne.

De fire udelukker ikke hinanden, men de følger to kontrasterende principper for, hvorfor deltagelse er vigtig: En liberal, humanistisk ideologi, som bygger på troen på, at kunstens autonomi kan transcendere social klasse over for et sociologisk syn på kultur som noget, der markerer og reproducerer sociale distinktioner. Det er disse to syn på kultur, som ifølge Kawashima konkurrerer inden for publikumsudviklingsdiskursen.

Ifølge Kawashima er idealet om kulturel universalisme fremherskende blandt publikumsudviklingsinitiativer i form af, hvad hun kalder en produktorienteret tilgang, hvor initiativerne tager udgangspunkt i det eksisterende kunstneriske "produkt". Hun peger på, hvordan udviklingen af et selvstændigt felt for "arts marketing”, herunder empiriske belæg for, hvem der faktisk bruger institutionerne, har leveret væsentlige bidrag til fremvæksten af diskursen om publikumsudvikling. Det er de danske kulturvaneundersøgelser (Bille, Kulturministeriet 2oI2a) et godt eksempel på, og de er fulgt op af en række mere specialiserede undersøgelser af f.eks. unges brug af museer (Moos og Lundgaard) og kulturforbruget i fem norske storbyer (Bjørnsen et al.). Publikumsudvikling handler i den sammenhæng om at nedbryde sociale og kulturelle barrierer hos publikum og kan, som også Hansen gør klart, forstås som en videreførelse af målsætningen om lige adgang for alle, som er grundlæggende i nordisk kulturpolitik.

At anerkende den sociologiske ide om kulturel separatisme vil på den anden side føre til, hvad Kawashima kalder en målgruppeorienteret tilgang. Den adskiller sig fra andre former for arts marketing ved at gøre selve produktet til noget, der udvikles i dialog med det publikum, man gerne vil have fat i. Det har, som hun forklarer, videre konsekvenser, da publikumsudvikling i denne forståelse ikke er afgrænset til at nå et nyt publikum, men også problematiserer "produkterne", herunder den eksisterende institutionelle praksis. Det er f.eks. hovedkonklusionen i rapporten "Not for the Likes of You", udgivet af Arts Council England. Her diskuteres en række kunstinstitutionernes aktiviteter, og hvordan de lykkedes med at nå målet om at nå et bredere publikum, og den vigtigste konklusion var entydig: 'succesfulde organisationer udfolder internt, hvad de gerne vil signalere til omverdenen' (Bayne et. al.,I3). Kort sagt: Det er ifølge den målgruppeorienterede tilgang ikke publikum, men institutionerne og deres udbud, som skal udvikles.

Louise Ejgod Hansen peger ligesom Kawashima på, hvordan publikumsudvikling som mål for kunstinstitutionerne kan føre til en ren brugerorientering, som i sin yderste konsekvens fører til radikale ændringer af kunstinstitutionens formål og daglige praksis på en måde, hvor det kunstneriske produkt - og ikke mindst den kunstneriske professionalisme - kommer i anden række. Målsætningen om kunstnerisk kvalitet har længe været skydeskive i diskussionen af mangfoldighed og diversitet, fordi den er blevet beskyldt for at forhindre anerkendelsen af alternative kunst- og kulturformer, der netop ikke lever op til de etablerede standarder for kunsten (se bl.a. Davies, Hermele, Skot-Hansen, Cultural Policy). Omvendt kritiseres den målgruppeorienterede tilgang for at reducere spørgsmålet om kunstnerisk tilfredshed til et spørgsmål om graden af tilfredshed hos det udvalgte publikum og om udbuddet på tilfredsstillende vis afspejler befolkningens kulturelle og sociale mangfoldighed (se bl.a. Hansen, Langsted).

Denne kompleksitet genfindes i Kawashimas brug af de to relaterede betegnelser som sin fjerde kategori: "out-reach" and "social inklusion". Hvor outreach opererer med publikum og ikke-publikum, omhandler inklusion socialt eller kulturelt ekskluderede grupper af befolkningen, uagtet om de bruger kunstinstitutionerne eller ej. Det bringer dermed institutionerne på ukendt grund, hvis deres mål bliver af en grundlæggende ikke-kulturel art (Kawashima, 58). Hvis inklusion er en central dagsorden for publikumsudvikling, må vi tilføje en femte kategori til Kawashimas fire, nemlig "anvendt kunst" (applied art). Her er målet fra institutionelt hold ikke at nå ud til et bredere publikum, men f.eks. at anvende teatermetodologier til at bemyndige (empower) særlige, udsatte grupperinger (Kerr 2). 
De tre indledende eksempler kan også beskrives inden for rammerne af Kawashimas kategorisering: Kunst-o-meter kan uden videre forstås som en blanding af smagskultivering og publikumsuddannelse, hvor det eksisterende publikum har mulighed at blive klogere på et givent værk og på at formulere sig om det - eller som museet selv formulerer det: "Målet med prosjektet er å gi publikum ordet og skape et forum for samtale om kunst. Ved å dele sin opplevelse kan man også utvide andres forståelse av kunsten."3 På samme måde kan Copenhagen Phils flashmob tilnærmelsesvist forstås som udvidet markedsføring. Her henvender orkestret sig til et nyt potentielt publikum på en måde, som gør opmærksom på orkestret og dets sæsonprogram, og som samtidig medvirker til orkestrets ønske om at markedsføre sig med et nyt image. Flashmob'en er dog i endnu højere grad et eksempel på "out-reach", idet orkestret møder deres potentielle publikum i for orkestrets uvante omgivelser. Det gælder både den konkrete optræden i metroen og i cirkulationen af den medierede udgave på de sociale medier. I begge tilfælde er der tale om produktorienteret tilgang til publikumsudvikling, hvor institutionens kerneværdier og kvalitetsforståelse nok tilføjes nye perspektiver, men ikke for alvor udfordres. At spille akustisk orkestermusik live i metroen og med et glimt i øjet, ${ }^{4}$ eller at give publikum ordet når en installations oplevelseskvaliteter skal forklares, overskrider, hvad vi traditionelt forstår ved symfoniorkestret og kunstmuseet som institutioner, men det er samtidig blot et lille tillæg til den eksisterende opførelses- og udstillingspraksis. Heroverfor står udstillingen In your face som et eksempel på Kawashimas målgruppeorienterede tilgang. Her er dialogen med det publikum, galleriet ønskede at få fat i - nemlig lokalbefolkningen - afgørende for udviklingen af udstillingens indhold, og med dette projekt lykkedes det "at trække galleriet væk fra dets modus operandi, hvor kuratorisk ekspertise er det helt afgørende, til en model hvor den besogendes oplevelse er $i$ centrum" (Brown og Novak 24). Det er i hvert fald konklusionen i rapporten "Getting in on the Act", som er udgivet af den amerikanske James Irving Foundation. For mens Kawashima kunne konkludere, at målgruppebaseret publikumsudvikling var sjældent, er der siden kommet flere eksempler på, "hvordan kunstgrupper skaber muligheder for aktiv deltagelse", som rapportens undertitel lyder.

I modsætning til Kawashimas brede interesse i publikumsudvikling (audience development) taler Brown og Novak specifikt om publikumsinvolvering (audience involvement). 5 Også her handler det om, hvordan kunstinstitutionerne kan tilpasse sig ændringer i det kulturelle og samfundsmæssige landskab. Ifølge Brown og Novak kræver ændrede forbrugsmønstre "nye og meningsfulde måder for folk at engagere sig på” (2), så når kunstinstitutionerne er tvunget til at arbejde ud fra et paradigmatisk skift fra "sid ned og bliv fortalt"-kultur til et "making and doing

3 http://www.museumstavanger.no/museene/stavanger-kunstmuseum/formidling/digital-formidling/ (besøgt 15.05.14)

4 Copenhagen Phil overrasker ved at være til stede på uvante steder og bringe den akustiske orkesterklang ud af koncertsalens mørk

5 Det samme gør f.eks. Nina Simons i the participatory museum (2010) kultur" er det ensbetydende med aktiviteter, hvor publikum bliver deltagere i den kunstneriske produktion ved at gøre, skabe og kreere noget eller ved at bidrage til et værks ide og koncept, uanset evner og erfaring (Ibid. 5).

Med dette udgangspunkt grupperes publikumsinvolvering i fem kategorier på et spektrum fra "receptiv" til "deltagende", hvor de to første falder ind under Kawashimas produktorienterede tilgang, mens de tre sidste udfolder hendes målgruppeorienterede tilgang.

\begin{tabular}{|l|l|}
\hline Kategorier for publikumsinvolvering & Beskrivelse \\
\hline $\begin{array}{l}\text { Iagttage } \\
\text { (Spectating) }\end{array}$ & $\begin{array}{l}\text { At iagttage er grundlæggende en hand- } \\
\text { ling, hvorigennem man modtager et } \\
\text { færdigt produkt. Det ligger derfor uden } \\
\text { for rammerne af deltagende kunst (par- } \\
\text { ticipatory art). }\end{array}$ \\
\hline $\begin{array}{l}\text { Udvidet engagement } \\
\text { Enhanced Engagement) }\end{array}$ & $\begin{array}{l}\text { Uddannelsesmæssigt eller værdi-tilfø- } \\
\text { jende aktiviteter som aktiverer publi- } \\
\text { kums kreative forestillingsevne, men } \\
\text { som ikke indebærer et selvstændigt } \\
\text { kreativt udtryk fra publikum. }\end{array}$ \\
\hline Crowd Sourcing & $\begin{array}{l}\text { Publikum aktiveres ved aktivt at træffe } \\
\text { valg eller bidrage med noget til det } \\
\text { kunstneriske produkt. }\end{array}$ \\
\hline $\begin{array}{l}\text { Sam-skabelse } \\
\text { (Co-creation) }\end{array}$ & $\begin{array}{l}\text { Medlemmer af publikum bidrager } \\
\text { med noget til den kunstneriske ople- } \\
\text { velse, som kurateres af en professionel } \\
\text { kunstner. }\end{array}$ \\
\hline Publikum-som-kunstner & $\begin{array}{l}\text { Når medlemmer af publikum tager sub- } \\
\text { stantiel kontrol over den kunstneriske } \\
\text { oplevelse. Fokus skifter fra produkt til } \\
\text { skabelsesproces. }\end{array}$ \\
\hline
\end{tabular}

$$
\text { Figur I: The Audience Involvement Spectrum (fra Brown \& Novak, s. 15, }
$$
min oversættelse)

Det er som eksempel på publikum-som-kunstner-princippet, at In Your Face fremhæves, fordi det netop forskyder institutionens fokus fra præsentation af produktet til facilitering af den skabende proces, et skift der kræver, at galleriet afgiver og overlader en del af kontrollen til publikum selv. Publikum udgøres her af museets 
brugere, såvel som lokalbefolkningen, og denne fokuseringen på et (lokal)samfunds hverdagspraksis er helt central for rapportens forståelse af kulturel værdi, som netop rejser spørgsmålet bvorfor hverdagslivets kunstneriske praksisser falder uden for organisationernes mission og værdisystem (8). "Kunstnerisk deltagelse" (art participation) er mange forskellige ting og rummer alt fra økonomisk støtte og tilstedeværelse over personlig praksis og tillid, men som Tepper og Gao peger på, er der i løbet af de seneste årtier sket en ændring fra et bredt demokratisk projekt til en snævrere interesse i hvem og hvor mange, der benytter de offentligt financierede non-profit kunstinstitutioner (I8). Hvor deltagelse i form af tilstedeværelse ('attendance') peger på kunstinstitutionernes arbejde som et lukket kredsløb, foreslår Brown \& Novak-Leonard at forstå kunstnerisk deltagelse som et 'økologisk system', der inkluderer alle led i 'fødekæden' og hvor alle involverede er afhængige af hinanden. Institutionernes afgørende udfordring er at gentænke deres egen rolle i dette system. Det betyder en bevægelse væk fra både målgruppetænkning og ideen om kunstens universelt humanistiske frigørelsespotentiale. I stedet bør, igen ifølge Brown \& Novak-Leonard, "communities" være omdrejningspunktet for publikumsudvikling - en tanke som også er udfoldet i dansk kontekst, når f.eks. Christian Have taler om et tranformativt kulturbegreb, der netop fremhæver institutionernes sociale engagement (Have). I naturlig forlængelse heraf falder flashmob'en uden for rammerne af Brown og Novak-Leonards definition af arts participation, idet passagererne i metroen fastholdes i rollen som betragtere. Her er situationen altså uvæsentlig. Det er lidt mindre klart, hvor Kunst-o-meter hører hjemme i modellen. Parallelt med Kawashimas "smagskultivering" og "publikumsuddannelse" er der tale om "enhanced engagement", men det er ikke klart hvorvidt publikums optræden i videoboksen kan siges at "involvere kreativt udtryk". Under alle omstændigheder hører også denne hjemme i den lavere ende af spektret, idet den ikke påvirker det kunstneriske produkt eller proces. Som inspirationskatalog over eksempler på 'best practice' er Brown \& Novak-Leonards rapport værdifuld, men den hjælper os ikke til at forklare potentialet i to af de tre eksempler, som indledningsvist er fremhævet som succesfulde. Hvordan det kan være, uddybes nedenfor, men først en kort kulturpolitisk ekskurs.

\section{Publikumsudvikling i et kulturpolitisk perspektiv}

For at forstå hvor stor en udfordring publikumsudvikling er for en grundlæggende institutionaliseret sektor (Hanke, Blomgren), er det værd at minde om, at de store kulturinstitutioner, herunder de fleste kunstinstitutioner, har rod i det klassiske, socialdemokratiske oplysningsideal, som var udgangspunktet for udviklingen af en selvstændig kulturpolitik i Skandinavien (Duelund, The Nordic cultural model). Målet var at forene forestillinger om demokrati, kunstnerisk frihed og social velfærd for at "opdrage og uddanne befolkningen til demokrati, stimulere kunstnerisk frihed og at sikre befolkningen lige adgang til kunstneriske oplevelser" (Duelund, Kunstens vilkår 34). Denne 'demokratisering af kulturen' afspejler et helt grundlæggende kulturpolitisk ideal om 'lige adgang for alle' uanset geografisk placering og social status: I mødet med kunsten findes potentiale for individets frigørelse og forestillinger om et bedre samfund, og dette potentiale overskrider samfundets øvrige skel. Samtidig fastholdes her en grundlæggende forestilling om, at nogle former for kultur er bedre end andre. Heroverfor står en pragmatisk kulturdefinition, hvor idealet om 'kulturelt demokrati' indebærer en ligestilling af de kulturelle udtryk, som eksisterer $i$ et givent samfund.

Det er let at forstå diskursen om publikumsudvikling ud fra dette dobbelte kulturbegreb, som har været bærende i nordisk kulturpolitik siden 70'erne (Nielsen, Skot-Hansen, Danish Cultural Policy...). ${ }^{6}$ Både Kawashimas skelnen og aktiv/ passiv-dikotomien lader sig let forklare i relation til hertil:

For det første står den produktorienterede over for den målgruppeorienterede tilgang som en parallel til distinktionen mellem demokratisering af kulturen og kulturelt demokrati. Mens det kulturpolitiske fokus traditionelt har handlet om at sikre diversitet $\mathrm{i}$ distributionen (at gøre kunsten tilgængelig for alle uanset geografisk placering og økonomisk formåen) såvel som i produktionen (at sikre at former for kulturelle udtryk har mulighed for at komme til udtryk) er det i publikumsudviklingsdiskursen ikke længere nok, at alle har lige adgang. Tværtimod skal der nu også være diversitet blandt de faktiske brugere af et givent kulturtilbud. For det andet peger forholdet mellem aktiv og passiv deltagelse på dette dobbelte kulturbegrebs skelnen mellem kultur som noget vi har - i form af anerkendte kunstværker og -institutioner, som vi kan vise frem for os selv og andre - eller noget vi er og som kommer til udtryk i den måde, vi lever og aktivt deltager i forskellige kulturelle praksisformer (Sørensen et al., 4I). Og med publikumsudvikling bringes dette skel ind i kunstinstitutionerne, hvis praksis traditionelt har fokuseret på at fremvise professionel kunst, og som nu også skal indeholde processer, som involverer publikum aktivt. Man kan sige, at publikumsudviklingsdiskursen efterlyser diversitet $\mathrm{i}$ de benyttede æstetiske strategier for interaktion - hvad enten der er tale om bidrag til tilblivelsesprocessen, inddragelse i afviklingsøjeblikket eller begge dele.

Der er, som Bjørnsen gør opmærksom på, slående ligheder mellem målene for den produktorienterede publikumsudvikling og tidligere tiders kulturelle paternalisme - publikumsudvikling som de nye vokabularium for traditionelle kulturpolitiske idealer. På den anden side bygger et fokus på kulturel diversitet på den underliggende præmis, at en kunstinstitutions ansatte og brugere skal repræsentere den demografiske fordeling af befolkningen for at være demokratisk. I sin mest radikale form implicerer det, at kunstnerisk kvalitet ikke længere kan være et kulturpolitisk mål. Det rejser derfor nogle fundamentale udfordringer for de principper, som støtten til kunstinstitutionerne reguleres efter (Hansen, 37, Skot-Hansen, Danish Cultural Policy, 208). Det er samtidig paradoksalt, hvis denne nye interesse

6 For en historisk og teoretisk diskussion af kulturbegrebet se Sørensen et al. (s. 29-52) og Michelsen \& Kierkega ard. For en nuanceret diskussion og problematisering af kulturel mangfoldighed og inklusion som kulturpolitisk betegnelse se Skott-Hansen, Danish Cultural Policy... og Kawashima. 
i publikum resulterer $i$, at publikum betragtes som repræsentanter for statistiske kategorier baseret på social klasse, alder, etnicitet, køn og handikap - noget som endda kan risikere at forstærke de selv samme kategorier (Nielsen).

I alle tilfælde flytter arbejdet med publikumsudvikling fokus fra diversitet som et ideal for kulturproduktion og - distributionskultur til også at handle om kulturvaner og deltagelsesformer, og ikke mindst er det ikke længere alene et fordelingspolitisk spørgsmål, men også en opgave for den enkelte institutions at sikre denne diversitet. Man kan spørge sig selv om ikke "kulturel diversitet" afspejler samtidens idé om kulturelt demokrati - noget der ifølge Dorte Skot-Hansen endnu ikke for alvor er kommet på den kulturpolitiske dagsorden:

"As I see it, our primary need is for an open discussion about quality and diversity, such that the concept of quality is not limited to promoting the familiar and the domestic to the exclusion of the foreign and distant. The concept of artistic quality itself must be viewed in a cultural context, and this perspective requires both an interest in and knowledge of the qualities and forms of expression of other cultures." (Danish Cultural Policy, 208)

Forholdet mellem kunstnerisk kvalitet og publikums oplevelser er ikke alene en væsentlig kulturpolitisk udfordring, det er også det forhold, som de tre indledende eksempler eksemplarisk sætter på spil: Hvad sker der, når institutionen afviger fra organisatoriske, tekniske og æstetiske forestillinger om kunstnerisk kvalitet, som er herskende inden for de respektive institutioner og genrer? Når orkestret udskifter koncertsalen med de ukontrollable akustiske forhold i metroen, når galleriet delvist overdrager det kuratoriske ansvar til publikum, eller når publikums vurderinger af en given forestillings eller installations kvalitet tages seriøst? Fælles for de tre eksempler er, at de alle udfordrer deres egen institutionelle praksis og dermed anerkender, at publikumsudvikling grundlæggende også handler om institutionsudvikling.

I skematisk form ser disse to for publikumsudviklingen centrale dagsordener sådan ud:

\begin{tabular}{|l|l|l|}
\hline & Målgruppeorienteret & Produktorienteret \\
\hline Aktiv & $\begin{array}{l}\text { Estetiske strategier for } \\
\text { interaktion }\end{array}$ \\
\hline Passiv & & $\begin{array}{l}\text { Kulturvaner og politisk } \\
\text { legitimering }\end{array}$ \\
\hline
\end{tabular}

Figur 2: skematisk fremstilling af den fremherskende publikumsudviklingsdiskurs
Produktorienteret publikumsudvikling bruger langt hen ad vejen udvidet markedsføring og publikumsuddannelse som midlet til at nå målet om et bredere publikum. Og eftersom det fra politisk hold ikke er klart, hvorvidt fokus er på særlige målgrupper, kan publikumsudvikling let reduceres til en legitimeringsstrategi for eksisterende kulturpolitiske prioritering. Målgruppeorienteret publikumsudvikling fokuserer på sin side på andre former for "aktiv" deltagelse som et middel til at nå nye publikumsgrupper. Her arbejdes med konkrete æstetiske strategier for interaktion ud fra en forventning om, at et opgør med eksisterende "passive" kulturelle konventioner er med til at nedbryde eksisterende barrierer. Æstetiske strategier for involvering kan derfor ses som en måde at skabe nye deltagelsesformer og derigennem et bredere publikum. Uanset om institutionerne er motiveret af kunstneriske ideer om socialt engagement eller af politisk dikterede krav om mangfoldighed og fornyelse. Der er altså en klar forventet sammenhæng mellem brugen af eksplicit involverende strategier og den demografiske sammensætning af publikum.

Ligesom det dobbelte kulturbegreb ikke længere er fyldestgørende og nye kulturstudier arbejder med et mere komplekst kulturbegreb (se f.eks. Sørensen et al.), synes også begge disse to dagsordener for publikumsudvikling at have et indbygget dilemma, der risikerer at fastholde diskussionen i velkendte dikotomier mellem på den ene side eksisterende kulturpolitiske idealer om fin- og populærkultur og på den anden side en ny normativ antagelse om, hvad "god deltagelse" er. Kort sagt en dårlig erstatning for de omstridte idealer for institutionaliseret professionel kunst, som publikumsudvikling grundlæggende problematiserer. Det lykkes da heller ikke på baggrund af hverken Kawashimas eller Brown-Novaks kategoriseringer at forklare det vellykkede ved alle tre eksempler, som indledningsvist blev fremhævet som gode eksempler på publikumsudvikling. Det er, hvad jeg afslutningsvis vil forsøge.

\section{Komplementare perspektiver på kunstinstitutionernes dilemmaer}

Et mere komplekst kulturbegreb er bl.a. kendetegnet ved en dynamisk og performativ kulturforståelse. Kultur er ikke bare noget, vi som samfund har og er, det er også noget, vi gør (Sørensen et al. ,42). Samtidig er det kendetegnet ved, at tidligere såvel som samtidige kulturbegreber sættes i spil i samme begreb (ibid 33ff). Det samme kan man sige om et mere komplekst begreb om publikumsudvikling. Selvom de to modsætningspar, der ligger til grund for den skematiske fremstilling af den fremherskende publikumsudviklingsdiskurs, er problematiske, betyder det ikke, at de to dagsordener, som hhv. Kawashimas og Brown \& Novak-Leonards kategoriseringer repræsenterer, er diskvalificeret i den videre diskussion. Snarere tilføjes andre forståelser samtidigt, nemlig to som sætter fokus på, hvad publikum faktisk gør med kunst og kunstinstitutionerne.

I den grafiske præsentation af publikumsudviklingsdiskursen ovenfor illustrerer sammenstillingen af 'aktiv' med 'målgruppeorienteret' Brown-Novaks forestilling 
om aktiv deltagelse som afgørende for publikumsoplevelsen. Men den forestilling er som allerede antydet problematisk. Det skyldes, at kategoriseringen er baseret på en velkendt binær opposition mellem aktiv og passiv deltagelse, en distinktion, der, som Jacques Ranciére gør opmærksom på, er “ ulighedens legemliggjorte allegorier. Det er derfor, man kan ændre termernes værdi og forvandle den 'gode' term til en dårlig og omvendt uden at ændre modsætningens egen funktion” (Rancière 27). Dette normative udgangspunkt gør ideen om "det aktive publikum" til et problematisk teoretisk koncept. Ideen kendes især fra medieforskningen, hvor den har været både fejret og kritiseret, og tilsvarende er forestillingen om, at fysisk aktivitet og konkret inddragelse er en garanti for samarbejde og demokrati grundigt kritiseret i forhold til forskellige kunstneriske praksisser (Ranciére, Bishop, Philipsen). Fra et kulturpolitisk perspektiv opfordrer Vestheim til at skelne analytisk mellem kulturpolitik og kultur ved at understrege, at 'cultural and artistic expressions are by themselves neither democratic nor anti-democratic' (498). Derudover er det et velkendt dilemma, at kunst som er afhængig af publikums konkrete bidrag eller er baseret på publikums egne (amatør)aktiviteter, ikke formår at fastholde interessen hos det publikum, som ikke er direkte involveret (Bishop). Dette dilemma gælder også In Your Face. Her er en del af succesen, at der blandt de besøgende til udstillingen var mange nye ansigter - som netop kom for at se sig selv eller nogle af de kendte. At udstillingen også vakte bredere interesse skyldes ikke mindst det overvældende antal bidrag og den - professionelle - kuratering, som de mange bidrag var organiseret efter. En konsekvens af afvisningen af denne fikserede definition af aktiv og passiv er, at også det stillesiddende publikum kan betragtes som aktivt deltagende. Fra et performance-teoretisk perspektiv er dette en grundlæggende antagelse. Enhver performance - eller ethvert kunstværk - er kun fuldendt i mødet med et publikum. Oplevelsen er defineret af kunstværkets æstetiske udtryk i relation til den sociale kontekst, de refleksive udtalelser, der omgiver den og den performative begivenhed, som mødet udspiller sig i. Deraf følger, at også de to 'lavere' kategorier i involverings-spektret kan betragtes som æstetiske strategier for involvering, hvor publikums deltagelse har betydning både for den enkelte og for det kollektiv, som publikum også udgør. "Spectatorship [...] is a form of active perception, where we are often (but not always) aware of ourselves looking", foreslår Matthew Reason med henvisning til Sartre (Reason, 20). Heraf følger, at også kombinationen af aktiv og produktorienteret træder frem som et selvstændigt perspektiv på publikumsudvikling. Her er det ikke involveringen i processen eller produktet, men publikums refleksioner, der er i centrum. På trods af den stærke tradition for at diskutere æstetisk erfaring, som ligger til grund for det universelt-humanistiske kunstideal, har publikumsudvikling indtil videre kun vist ganske lille interesse for publikums oplevelser af det kunstneriske produkt. Hvor involverings-spektret fokuserer på selve den performative situations her-og-nu, peger Matthew Reason under overskriften "Asking the audience" på betydningen af det, han kalder "the post-performance experience". Med reference til medievidenskabens lange tradition for receptionsstudier argumenterer han for, at betydningen af de spor, som situationen efterlader hos den enkelte tilskuer såvel som publikum som gruppe, ikke blot er en svag, fikseret skygge af den egentlige oplevelse. Snarere skal vi, foreslår han, interessere os for receptionsprocessen, som den foregår i publikums sociale og mentale liv, hvor en given forestilling afføder mange og forskelligartede former for efterliv, erindringer, konnotationer, refleksioner (26).

Spørgsmålet om hvilke spor de æstetiske oplevelser efterlader hos deltagerne, benævnes hos Reason "post-performance refleksion". Fra tidlige empiriske publikumsundersøgelser med Richard Sauters 'teaterdialoger' (Sauter et al.) som et godt eksempel, er dette spørgsmål først for nyligt blevet genoptaget (Reason, Schollen, Radbourne et al., Lindelof \& Hansen), men publikums faktiske oplevelser spiller endnu ingen egentlig rolle for forståelsen af publikumsudvikling. Fælles for flere af disse studier af publikums oplevelser er, at publikum ofte fremhæver muligheden for at dele deres oplevelse efter forestillingen som noget positivt, som samtidigt medvirker til at forbedre oplevelsen - og dermed er post-performance refleksion ikke kun af erkendelsesmæssig interesse, det er også et håndgribeligt mål for publikumsudviklende initiativer (Lindelof og Hansen): Publikum behøver ikke nødvendigvis at deltage i den kunstneriske proces eller blive fysisk aktiveret af produktet for at føle sig involveret. Også muligheden for at dele oplevelsen med andre under mere eller mindre iscenesatte former opleves som deltagelse. Det er ud fra dette perspektiv let at forklare Kunst-o-meters potentiale.

Også et andet perspektiv på, hvad publikum 'gør' med det kunstneriske produkt, er nedtonet i publikumsudviklingsdiskursen, nemlig spørgsmålet om, hvordan sådanne spor - den æstetiske erfaring - integreres i hverdagslivet. Dette perspektiv er ideelt set forbundet med den post-performative refleksion og udgør i den sammenhæng en metodisk såvel som erkendelsesmæssig udfordring: "The limitlessness of the post-performance experience - ending only in death" (Reason, 20). Dermed anerkendes også den æstetiske erfarings forandringspotentiale - hvad enten det sker i mødet med en stærk kunstnerisk intention, som når Erika Fischer-Lichte taler om "the transformative power of performance" eller med afsæt i musikalske hverdagsoplevelser, som når Tia DeNora i sit berømte studie af "music in everyday life" indledningsvist overrasket bemærker "just how much of what I observed in relation to music's powers could simply not have been imagined in advance." (ix).

Integrationen af amatørernes praksis i den professionelle institution er udtrykt i Brown og Leonard-Novaks involverings-spektrum, men ud over ønsket om at basere institutionernes initiativer på folks aktive kunstneriske og kreative praksis, er der her også tale om at få den professionelle praksis til at spille bedre sammen med hverdagslivet, som det foregår uden for institutionernes mure. Det ligger i tråd med Kawashimas kategori om 'outreach', hvor bestemte publikumsgrupper kan møde kunsten uden at skulle tage en aktiv beslutning om at opsøge den. Samtidig aktualiserer hverdagsperspektivet også den kunstneriske avantgardes lange tradition for netop at overskride grænsen mellem kunst og hverdag. Når orkestret forstyrrer deres potentielle publikums daglige transportrutiner, kan det 
ses som en simpel illustration af begge dele. Heroverfor står både In Your Face og Kunst-o-meter som eksempler på, hvordan en eksisterende hverdagspraksis bliver integreret $\mathrm{i}$ institutionens praksis.

På baggrund heraf ser en opdateret grafisk fremstilling af publikumsudviklingsmatrixen sådan ud:

\begin{tabular}{|l|l|l|}
\hline & Synkront, situationelt & Diakront, forandring \\
\hline Enkeltstående initiativer & $\begin{array}{l}\text { Estetiske strategier for } \\
\text { interaktion }\end{array}$ & $\begin{array}{l}\text { Post-performance reflek- } \\
\text { sion }\end{array}$ \\
\hline
\end{tabular}

Figur 3: publikumsudviklingens fire perspektiver

\begin{tabular}{|l|l|l|}
\hline Institutionel organisering & Hverdagspraksis & $\begin{array}{l}\text { Kulturvaner og politisk } \\
\text { legitimering }\end{array}$ \\
\hline
\end{tabular}

Der er tale om fire perspektiver, der inden for kulturforskningen udfoldes som selvstændige interessefelter i form af hhv. interaktionsdesign, æstetisk teori, socialantropologi og kultursociologi, men som i relation til publikumsudvikling sjældent artikuleres som selvstændige områder. En anden måde at beskrive modellens fire felter er denne: Den venstre side fokuserer på det synkrone, situationelle perspektiv - på handling og affekt, den højre på den diakrone forandringsperspektiv - på betydning og effekt. Den øverste trækker på en grundlæggende kunstfaglig og æstetikfilosofisk interesse suppleret af nyere interaktionsdesign, hvor fokus er på enkeltinitiativer, mens den nederste afspejler mere sociologisk orienterede aspekter af kultur og i højere grad handler om et perspektiv på, hvordan et publikumsfokus kan medtænkes $\mathrm{i}$ institutionens daglige organisering og ledelse.

Kendetegnende for både den post-performative refleksion og for hverdagsperspektivet er, at de i modsætning til de to første perspektiver ikke lader sig måle i kulturvaneundersøgelser eller vise på video. De er kort sagt sværere at undersøge, ligesom effekten ikke lader sig umiddelbart dokumentere. Med henvisning til Winkelhorns kritik af publikumsudvikling som den "politiske parallel til markedets adaption af teater" (56) kan man sige, at ideen om publikumsudvikling afspejler en generel diskrepans i den offentlige kulturelle diskurs - der med Ron Eyermans ord 'næsten er lykkedes med at identificere viden med fornuft og at reducere kunst til spørgsmål om smag, distinktion og økonomisk vinding'(2I).

Et fundamentalt spørgsmål står tilbage: I hvilken grad er social inklusion et centralt mål for publikumsudvikling? Og i forlængelse heraf: Hvad bør være konsekvenserne af den demografiske ulighed blandt brugerne af de offentligt finansierede kunstinstitutioner? Som vi har set, fokuserer den eksisterende publikumsudviklingsdiskurs på et institutionelt og kulturpolitisk perspektiv, men som artiklen peger på, kan man ligeså godt argumentere for, at det er kunstinstitutionerne, der skal integreres bedre i befolkningens hverdagsliv. Som det fremgår af ovenstående diskussion, er et fokus på inklusion problematisk, da det let kommer til at reproducere en velkendt og uproduktiv dikotomi mellem en humanistisk-idealistisk tro på den professionelle kunsts demokratiske potentiale på den ene side og et relativistisk argument baseret på reproduktion og repræsentativitet på den anden. For hvem er det egentlig, der skal inkluderes - og i hvad?

Det er der ikke noget enkelt svar på. Dens fire perspektiver er tænkt som et grafisk værktøj til en mere nuanceret diskussion af vægtningen af de enkelte perspektiver og af sammenhængen imellem dem, når der diskuteres mål og midler for såkaldt publikumsudviklende aktiviteter. Interessen for publikumsudvikling har potentiale til at overskride disse delvist modsætningsfyldte forståelser af kultur og betydningen af kulturel praksis. Det er i relationen mellem publikum, værk, institution og det omgivende samfund, at kunstinstitutionerne kan være andet og mere end kunst-arkiver og sociale reservater, og dette potentiale kan først for alvor udfoldes, hvis kunstinstitutioner og kulturpolitikere anerkender det komplekse samspil mellem alle fire perspektiver, også det, som jeg ovenfor kalder hhv. hverdagspraksis og post-performance refleksion.

\section{Konklusion}

Opsummerende kan man sige, at publikumsudvikling er en kulturpolitisk respons på store samfundsmæssige forandringsprocesser, som udfordrer kunstinstitutionernes selvforståelse og historiske raison d'etre. Det er kort sagt et udtryk for et aktuelt politisk imperativ om at ændre institutionernes publikumssammensætning. Som nærværende artikel argumenterer for, risikerer den eksisterende diskurs om publikumsudvikling med sin organisatoriske og institutionaliserede kulturbegreb at fastholde eksisterende dikotomier mellem høj-lav, aktiv-passiv, offentlig-privat, som begrebet ideelt set ønsker at overkomme. Denne publikumsudviklingsdiskurs har altså væsentlige mangler, som risikerer at fastholde forholdet mellem institutionerne, kulturpolitikken og publikum som en statisk størrelse. For at supplere den eksisterende diskurs peger artiklen på, at to komplementære perspektiver på publikumsudvikling er nødvendige: post-performative refleksion og hverdagspraksis. Her er det grundlæggende spørgsmål ikke, for hvem institutionernes udbud af kunst har betydning, men snarere hvordan det betyder noget. Diversitet skal ikke kun findes i udbud og efterspørgsel, men også i forhold til en nuanceret forståelse af, hvad deltagelse vil sige på tværs af æstetiske strategier for interaktion og normative forestillinger om aktiv og passiv deltagelse. Heraf følger også en grundlæggende accept af de mangfoldige individuelle reaktioner på samme æstetiske udtryk. Lidt mere firkantet formuleret peger det på nødvendigheden af at få et performance-teoretisk og etnografisk perspektiv på banen som modvægt til den grundlæggende sociologiske og markedsøkonomiske diskurs, der sammen med løse forestillinger om interaktion synes at udgøre publikumsudviklingsdiskursens 
kerne. Det er hverken publikum, der skal udvikles, eller institutionerne, der skal opløses i brugerdrevne kulturhuse. Vellykket publikumsudvikling derimod insisterer på et komplekst forhold mellem I) æstetiske strategier for interaktion, 2) post-performance refleksion, 3) institutionernes og publikums hverdagspraksis og 4) kulturvaner og politisk legitimering. Og det er ikke mindst i forholdet imellem disse fire perspektiver, at de interessante spændinger findes. Publikumsudvikling er altså - hvis det skal være andet og mere end kulturpolitisk legitimering eller institutionel markedsføring - en kompleks størrelse, og udfordringen for både kunstinstitutioner, kulturpolitikere og publikumsforskningen ligger $i$ at fastholde denne kompleksitet.

De forandringer, som publikumsudvikling forsøger at skabe, sker ved ikke at monopolisere diskussionen om deltagelse. Mangfoldighed findes ikke bare på, foran og bag scenen, men også når (lokal)samfundet, publikums oplevelser og hverdag integreres $\mathrm{i}$ institutionens egen praksis.

\section{LITTERATURLISTE}

Aidt, Mik, Sofie Henningsen \& Niels Righolt.. Fra guder til tienere. København: CKIs Publikation, hentet på http://www.kunstoginterkultur.dk/20I2/pdf/Fra-guder-til-tjenere.pdf, 20I2, [besøgt november 2013].

Bille, Trine, et al.. Danskernes kultur- og fritidsaktiviteter 2004 - med udviklingslinjer tilbage til 1964. København: AKF Forlaget. 2005.

Bishop, Claire. Artificial hells: participatory art and the politics of spectatorship. London: Verso. 2012.

Bjørnsen, Egil. "Publikumsutviklingens begrensninger”. K. Danielsen, red. Om publikumsutvikling. Bergen: Norsk publikumsutvikling, 20I0. I09-III

Bjørnsen, Egil, Lind, E., \& Hauge, E.. Kunstkonsum i storbyene. En studie av brukere og ikke-brukere av det offentlig finansierte kunsttilbudet $i$ byene. Oslo: Agderforskning. 20I2.

Blomgren, R., 20I2. "Autonomy or democratic cultural policy: that is the question". International journal of cultural policy, I8 (5). (2012): 519-529.

Brown, A. and Novak-Leonard, J.L.. Getting in on the act: how arts groups are creating opportunities for active participation. San Fransisco, CA: The James Irvine Foundation, 20II.

Butsch, Richard. The citizen audience: crowds, publics and individuals. New York: Routledge, 2008.

Couldry, Nick, Why Voice Matters. Culture and Politics after Neoliberalism. London: Sage, 2010.

Moos, Thyge. \& Lundgaard, Ida B. (Red.). En mailgruppeundersogelse af museernes unge brugere og ikkebrugere. København: DAMVAD, 2010.

Danielsen, Kristin (red.). Om publikumsutvikling. Bergen: Norsk publikumsutvikling. 2010 Davies, Trevor. Kulturel Mangfoldighed. Inspiration til kunstrådet [online]. Kulturministeriet. Www.kum. $\mathrm{dk}$ 2007. [besøgt Jan 2013].

DeNora, Tia. Music in Everyday Life. Cambridge: Cambridge University Press, 2000.

Duelund, Peter. Kunstens vilkair - om de kulturpolitiske tendenser i Danmark og Europa. Copenhagen: Akademisk Forlag. 1995
Duelund, Peter (red.). The Nordic cultural model. Nordic cultural institute. Copenhagen: Akademisk Forlag. 2003.

Eyerman, Ron. "Towards a meaningful sociology of the arts". R. Eyerman \& L. McCormick, (red.). Myth, meaning and performance. London: Paradigm Publishers, 2005. I3-34.

Forsare, Malena \& Lindelof, Anja (Red). Publik i Perspektiv. Lund: Makadams Forlag. 20I3.

Hall, Stuart. "The work of representation". Stewart Hall, red. Representation: cultural representation and signifying practices. London: Sage, 1997. I3-74.

Hanke, Peter. Kulturens skjulte styrker. København: Gyldendal, 20II.

Hansen, Louise Ejgod. Hvad er publikumsudvikling? [online]. Report No. I. Randers:

Scenekunstnetværket Region Midtjylland. Http://www.scenet.dk/publikationer.html 2oII [besøgt november 20I3]

Hermele, Vanja.. Teaterchef och gatekeeper. Konsten att kanonisera med begreppet konstnärlig kvalitet. Afhandling. University of Stockholm, 2006.

Kawashima, Nobuko. Beyond the division of attenders vs. non-attenders: a study into audience development in policy and practice. Coventry: Centre for Cultural Policy Studies, University of Warwick. 2000.

Kerr, David. Theatre for development. K. Wilkins, T. Tufte, \& R. Obregon, (Red.). Development, communication and social change. Boston, MA: Wiley, 2013, 207-225.

Kulturministeriet. Reach out! - inspiration til brugerinddragelse og innovation I kulturens verden. Kulturministeriets tværgående projektgruppe [online]. Www.kum.dk 2008 [Jan 20I3]. Kulturministeriet. Kultur for alle [online]. Www.kum.dk 2009. [Jan 20I3]

Kulturministeriet. Danskernes Kulturvaner 20I2. Udarbejdet af: Epinion A/S og Pluss Leadership A/S [online]. Www.kum.dk, 20I2a. [Jan 20I3].

Kulturministeriet. En Musikscene - Mange genrer. Musikhandlingsplan 20I2-20I5 [online]. Www.kum.dk, 20I2b [May 20I2].

Langsted, Jørn (ed.). Spendvidder, Aarhus: Klim, 2010

Lindelof, Anja. "Det, at det var livelive. en undersøgelse af publikums oplevelser af fore- stillingen Jeg er drømmenes Labyrint." Peripeti, I8 (20I2): 8-22.

Lindelof, Anja M. og Hansen, Louise Ejgod. "Teatersamtaler: Publikumsudvikling gennem dialog.” M. Forsare \& A. Lindelof, eds. Publik i Perspektiv: Teaterarbete i Oresundsregionen. Makadam Förlag: Göteborg, 2013. I37-I57.

Lindelof, Anja M.. "Audience Development and its blind spot." International Journal of Cultural Policy (epublishing ahead of press). 2014

Maitland, Heather. A guide to audience development. London: Arts Council of England. 1997.

Møller, Søren F. From disinterestedness to engagement: towards relational leadership in the cultural sector. Dissertation. Copenhagen: CBS. 2012

Bayne, Debbie, Seamus Smyth, Maddy Moron, Mel Larsen. Not for the likes of you. How to reach a broader audience. Edinburgh: Morton Smyth Ltd for Arts Council. 2004

Nielsen, Henrik Kaare. 20I2: “Aesthetic judgement and political judgement." Nordic Journal of Aesthetics, 43 (2OI2): 7-I7

O'Reilly, D. \& Kerrigan, F., eds. Marketing the arts: a fresh approach. London: Routledge, 2010.

Philipsen, Lotte. "The myth of emancipation through interaction". The Nordic journal of aesthetics, 43 (20I2): I8-32. 
Radbourne, Jennifer, Johanson, K., \& Glow, H., 20Io. "Empowering audiences to measure quality.” Participations, 7: 2 (2010): 360-379.

Ranciére, Jacques. "Den frigjorte tilskuer.” KひK II8 (20I4): 2I-33 .

Reason, Matthew. "Asking the audience. Audience research and the experience of theatre". About performance, IO. (2010):I5-34.

Sauter, Wilmar., Isaksson, C., \& Jansson, L.. Teaterögon. Publiken möter föreställningen. Upplevelse - utbud - vanor. Stockholm: Liber, I986.

Skot-Hansen, Dorte. Byen som scene - kultur-og byplanlagning $i$ oplevelsessamfundet. Frederiksberg: Bibliotikarforbundet, 2007

Skot-Hansen, Dorthe, "Danish Cultural Policy - From Monoculture Towards Cultural Democracy." International Journal of Cultural Policy, 8: 2 (2010): 197-2IO

Schrøder, Kim, Drotner, Kirsten, Murray, C., \& Kline, S., 2003. Researching audiences. London: Arnold, 2003.

Scollen, Rebecca. "Talking theatre is more than a test drive. Two audience development methodologies under review." International journal of arts management, I2: 4 :(2009): 4-I3.

Simon, Nina. The participatory museum. Santa Cruz, CA: Museum. 2010.

Sørensen, Anne Scott, Ole Høystad, Erling Bjurstrøm \& Halvard Vike. Nye Kulturstudier. Teorier og temaer. København: Tiderne skifter, 2010

Tepper, S.J. and Gao, Y. "Engaging art: what counts?” S.J. Tepper \& B. Ivey, eds. Engaging art: the next great transformation of America's cultural life. New York: Routledge, 2008, I7-48.

Vestheim, Geir. "Cultural policy and democracy: an introduction.” International journal of cultural policy, I8: 5(2012): 493-504.

Winkelhorn, Kathrine. "Fra Publikumsudvikling til Teaterudvikling." M. Forsare \& A. Lindelof (red.). Publik i Perspektiv: Teaterarbete i Oresundsregionen. Makadam Förlag: Göteborg, 20I3. 95-II3. 